\title{
Physical and Chemical Technologies of Metal Mining and Water Resources
}

\author{
Vladimir I. Golik*a,b, Maria Yu. Liskova ${ }^{c}$, \\ Yadviga G. Nebylova ${ }^{d}$ and Chainesh B. Kongar-Syuryun ${ }^{\mathrm{e}}$ \\ ${ }^{a}$ North Caucasian Institute of Mining and Metallurgy \\ Vladikavkaz, Russian Federation \\ ${ }^{b}$ South-Russian State Polytechnic University \\ Novocherkassk, Russian Federation \\ ${ }^{c}$ National Research Polytechnic University \\ Perm, Russian Federation \\ ${ }^{d}$ Kuban State University \\ Krasnodar, Russian Federation \\ eNational Research Technological University "MISiS", \\ Moscow, Russian Federation
}

Received 24.11.2020, received in revised form 18.01.2021, accepted 12.03.2021

\begin{abstract}
The article is devoted to minimizing the negative impact of mining on the water resources of the mining regions. An assessment is made of leaching technologies with the involvement of non-conventional reserves for traditional methods of mining, reducing costs and lowering the level of environmental impact, including water resources. A reference is given on the use of leaching technologies for the development of natural and technogenic deposits in Russia. The mechanism of contamination of water resources with reagents and products of ore mining and processing is described. The typification of the processes of water migration of substances and components of underground leaching solutions is proposed. The zones of interaction between mineral deposits and water resources are differentiated. Fundamental differences of technology are formulated by the criterion of impact on water resources. An example of preventing the mixing of clean water and industrial effluents by creating a barrier in practice of a mining enterprise is given. It is concluded that the use of technologies with leaching of metals from ores at the place of their localization is promising.
\end{abstract}

Keywords: water resources, leaching technology, environment, reagent, industrial effluents, damage.

Citation: Golik V. I., Liskova M. Yu., Nebylova Ya. G., Kongar-Syuryun Ch. B. Physical and chemical technologies of metal mining and water resources, J. Sib. Fed. Univ. Eng. \& Technol., 2021, 14(2), 175-186. DOI: 10.17516/1999-494X-0298

(C) Siberian Federal University. All rights reserved

This work is licensed under a Creative Commons Attribution-Non Commercial 4.0 International License (CC BY-NC 4.0).

* Corresponding author E-mail address: v.i.golik@mail.ru

ORCID: 0000-0002-1181-8452 


\title{
Физико-химические технологии добычи металлов
}

\section{и водные ресурсы}

\author{
В.И. Голик ${ }^{\mathrm{a}, \boldsymbol{\sigma}}$, М. Ю. Лискова ${ }^{\mathrm{B}}$, \\ Я.Г. Небылова \\ ${ }^{a}$ Северо-Кавказский государственный технологический университет \\ Российская Федерация, Владикавказ

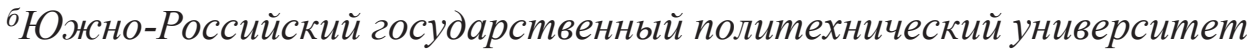 \\ Российская Федерация, Новочеркасск \\ ${ }^{8}$ Национальный исследовательский политехнический университет \\ Российская Федерачия, Пермь \\ Кубанский государственный университет \\ Российская Федерация, Краснодар \\ дНациональный исследовательский \\ технологический университет «МИСиС» \\ Российская Федераџия, Москва
}

\begin{abstract}
Аннотация. Статья посвящена минимизации негативного воздействия горного производства на водные ресурсы добывающих регионов. Дана оценка технологий выщелачивания с вовлечением в эксплуатацию некондиционных для традиционных способов добычи запасов, уменьшением затрат и снижением уровня воздействия на окружающую среду, в том числе на водные ресурсы. Дана справка об использовании технологий выщелачивания в разработке природных и техногенных месторождений России. Описан механизм загрязнения водных ресурсов реагентами и продуктами добычи и переработки руд. Предложена типизация процессов водной миграции веществ и компонентов растворов подземного выщелачивания. Дифференцированы зоны взаимодействия месторождений полезных ископаемых с водными ресурсами. Сформулированы принципиальные различия технологии по критерию воздействия на водные ресурсы. Приведен пример предупреждения смешивания чистых вод и промышленных стоков путем создания барьера на практике добывающего предприятия. Сделан вывод о перспективности использования технологий с выщелачиванием металлов из руд на месте их локализации.
\end{abstract}

Ключевые слова: водные ресурсы, технология выщелачивания, окружающая среда, реагент, промышленные стоки, ущерб.

Цитирование: Голик, В.И. Физико-химические технологии добычи металлов и водные ресурсы / В.И. Голик, М. Ю. Лискова, Я. Г. Небылова, Ч. Б. Конгар-Сюрюн // Журн. Сиб. федер. ун-та. Техника и технологии, 2021, 14(2). C. $175-186$. DOI: $10.17516 / 1999-494 X-0298$

\section{Введение}

Обладая крупнейшими запасами руд цветных металлов и добывая 5 \% мирового минерального сырья в денежном выражении, Россия не обеспечивает свою сырьевую безопасность по ряду цветных металлов. Большая часть благородных металлов добывается попутно, а добыча редких металлов и рассеянных элементов практически не осуществляется. Недостаточность сырьевой базы для удовлетворения запросов промышленности формирует проблему модернизации технологий добычи цветных металлов, связанную с глобальными задачами обеспечения жизнедеятельности в условиях демографических явлений, снижения содержания металлов в рудах с глубиной горных работ, усложнения условий разработки и др. [1-4].

$$
-176-
$$


Одним из направлений решения проблемы является освоение некондиционных природных и техногенных месторождений инновационными физико-химическими технологиями с вовлечением в эксплуатацию непригодных для традиционных способов добычи руд, которые противопоставляются технологиям с обрушением, с твердеющей закладкой, с открытым выработанным пространством. Эти технологии имеют свою историю, освоены в промышленных масштабах и располагают хорошей перспективой развития [5-8].

Вместе с тем освоение физико-химических технологий рождает комплекс трудно решаемых вопросов взаимодействия с природными условиями существования биоты в экосистемах окружающей среды, в первую очередь в гидросфере как транспортирующей химические продукты новой технологии и связующей все экосистемы окружающей среды [9-12].

Физико-химические технологии разработки вступают в конфликт с живым веществом, изменяя условия существования водных ресурсов, поэтому согласование интересов горнопромышленных предприятий и принципов экологизации промышленного производства является целью исследований последнего времени и настоящей статьи [13-17].

\section{Результаты и обсуждение}

Проблема сохранения водных ресурсов от технологического загрязнения исследуется на практике промышленно развитого Юга России, располагающего большими водными ресурсами.

Каспийское море питают реки Волга, Терек, Кума, Сулак, Самур, Калаус и несколько десятков мелких рек.

Азовское море - уникальный водоем площадью 38 тыс. км², жизнь которого связана с рекой Дон, обеспечивающей 2/3 материкового стока. В пределах Юга России около 36 тыс. рек протяженностью почти 150 тыс. км. Только в Дагестане 6255 рек, большинство из которых имеют длину менее 10 км. 21 река впадает в море.

Дон - одна из крупнейших рек европейской части России. Длина его 1870 км, площадь водосбора 442 тыс. км². К крупным рекам относится также Северский Донец. Средние реки Сал, Западный Маныч, Калитва. Малые и средние реки представлены 21 бассейном, включающим 165 рек суммарной длиной 9565 км.

Кубань располагается в пониженной части предгорной равнины. Вдоль побережья Азовского моря расположены мелководные соленые заливы.

Каспийское море питают реки Волга, Терек, Кума, Сулак, Самур, Калаус и несколько десятков мелких рек. По насыщенности гидро-энергоресурсами выделяются реки Дагестана. Первенствует река Сулак, среднегодовой сток ее превышает $170 \mathrm{~m}^{3} / \mathrm{c}$.

Озера округа насчитывают около 5 тыс. водоемов общей площадью почти 6 тыс. км². Цимлянское водохранилище в пределах Ростовской и Волгоградской областей имеет площадь


стях и имеет площадь 3117 км², объем 31,5 км³ и длину 540 км. Краснодарское водохранилище имеет площадь 400 км², объем 2,3 км³ $^{3}$, длину 40 км, наибольшую ширину 15 км и среднюю глубину 6 м.

Ледники в количестве более 1400 единиц общей площадью около 1 тыс. км² питают реки Кубань, Терек, Сулак, Самур и др.

$$
-177-
$$


Пресные воды в пределах Предкавказья и Ростовской области оцениваются в 100-110 км³. Запасы воды в ледниках 85 км³. $^{3}$

Металлические месторождения Юга России включают в себя широко известное Тырныаузское (Кабардино-Балкария) и Ктитебердинское (Карачаево-Черкесия) месторождения вольфрамомолибденовых руд, Садонское (Северная Осетия - Алания) свинцово-цинковых руд, Урупское месторождение меди (Карачаево-Черкесия), медные руды (Дагестан). Важнейшими ископаемыми рудной минерагении являются черные, цветные, благородные, редкие металлы и рассеянные элементы.

Урупский горно-металлургический комбинат эксплуатирует Урупское и Власенчихинское месторождения. Тырныаузский вольфрамово-молибденовый комбинат отрабатывал Тырныаузское месторождение комбинированно: верхнюю часть карьерами «Высотный» и «Мукуланский», нижнюю - подземным рудником «Молибден». Садонский свинцово-цинковый комбинат располагает более 150 полиметаллическими месторождениями.

Эксплуатации месторождений присущи закономерности развития:

- увеличение объема добычи руд при уменьшении содержания металлов в руде;

- селективная выемка с деконцентрацией работ и оставлением целиков;

- разрушение массива с увеличением объема разубоживающих пород.

Хвосты переработки металлических руд хранятся на территориях добывающих регионов, активно воздействуя на водные ресурсы (рис. 1).

При разработке ряда природных и техногенных месторождений России получают развитие физико-химические технологии с использованием феномена выщелачивания металлов из вскрываемых руд (табл. 1).

Горные предприятия своей деятельностью нарушают природные процессы. Предприятия России извлекают на поверхность более 1,3 млрд м² сточных вод в год. В виде взвесей выбрасываются тысячи тонн комплексных руд. Рудничные воды содержат медь, железо, серу в концентрациях, соизмеримых с их содержанием в рудах, а концентрации цинка и кадмия превышают эти величины.

Горные объекты принимают слабоминерализованные воды и выдают на поверхность влияющие на прилегающие регионы высокоминерализованные воды: технологические хвосты

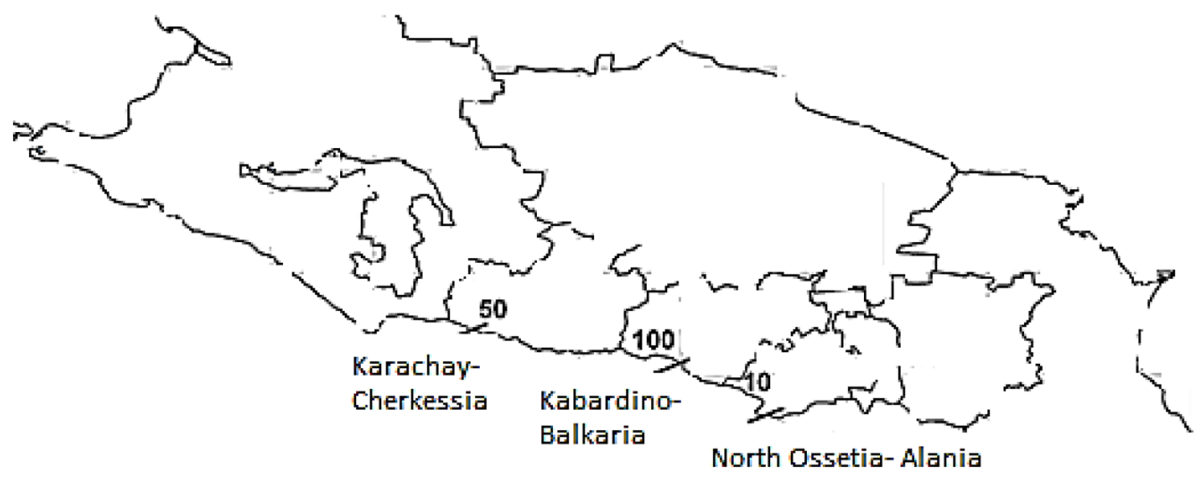

Рис. 1. Запасы техногенных месторождений, млн тонн

Fig. 1. Reserves of technogenic deposits, million tons 
Таблица 1. Выщелачивание металлов на месторождениях России (2017 г.)

Table 1. Leaching of metals at Russian deposits (2017)

\begin{tabular}{|l|l|l|}
\hline \multicolumn{1}{|c|}{ Металл } & \multicolumn{1}{|c|}{ Месторождение, технология } & \multicolumn{1}{c|}{ Регион } \\
\hline \multirow{5}{*}{ Медь } & Техногенные месторождения & Свердловская обл. \\
\cline { 2 - 3 } & & Мурманская обл. \\
\cline { 2 - 3 } & Гумешевское, подземное выщелачивание & Красноярский край \\
\hline \multirow{2}{*}{ Никель-кобальт } & Аллареченское & Свердловская обл. \\
\cline { 2 - 3 } & Хвостохранилище № 1 & Мурманская обл. \\
\cline { 2 - 3 } & Озеро Барьерное & Красноярский край \\
\hline Цинк & Шлакоотвал & Свердловская обл. \\
\hline Олово & Техногенные месторождения & Бурятия \\
\hline Вольфрам & Барун-Нарынское & Забайкальский край \\
\cline { 2 - 3 } & Спокойнинское & Читинская обл. \\
\hline Уран & Стрельцовское, подземное и кучное выщелачивание & Забайкальский край \\
\hline Титан & Кручининское, скважинное & \\
\hline
\end{tabular}

обогащения, сливы и фильтрат от сгущения и обезвоживания, шахтные стоки атмосферного и природного происхождения (рис. 2).

Составными частями промышленных сточных вод горнодобывающих предприятий являются шахтные воды, а также стоки атмосферных вод, загрязненные вследствие водной эрозии отвалов пород и некондиционного сырья.

При геотехнологических методах разработки воды используются для растворения, выщелачивания и транспортировки полезных ископаемых. К загрязнителям относятся химические ингредиенты, остающиеся в недрах, и водные отходы переработки выдаваемых на поверхность «рассолов».

Промышленные стоки, поступающие в технические водоемы - пруды, различного вида отстойники, - оказывают существенное влияние на статические запасы и гидродинамические режимы подземных вод.

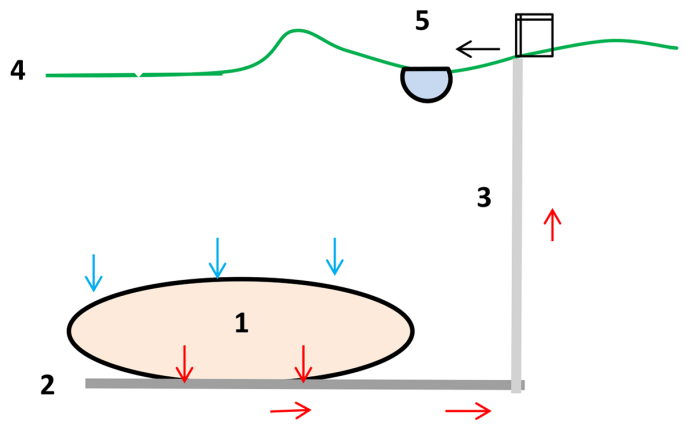

Рис. 2. Схема движения потоков: 1 - месторождение; 2 - приемник растворов; 3 - выдающая выработка; 4 - шахтная поверхность; 5 - река

Fig. 2. Flow pattern: 1 - field; 2 - solution receiver; 3 - outstanding output; 4 - shaft surface; 5 - river 
Химико-минералогический состав месторождений непостоянен. При понижении уровня горных работ содержание металлов уменьшается, а отделенная от массива руда, не отвечающая кондициям в рассматриваемый период времени, остается в пустотах, формируя техногенные месторождения потерянных руд.

Эти руды могут быть использованы для выщелачивания. Выщелачивание руд из вскрываемых металлов происходит вследствие сложных химических реакций нередко с образованием новых соединений, опасных для водных ресурсов региона.

Способ подземного выщелачивания реализуется путем подачи в выработанное пространство выщелачивающего раствора и выдачи продуктивного раствора на переработку.

Условиями отработки месторождения выщелачиванием служат предварительное водопонижение и осушение, а также поддержание шахтного водоотлива в период эксплуатации месторождения, которое является дреной.

Рабочий раствор обычно представляет собою водный раствор серной кислоты, карбонатов и бикарбонатов. Поток рабочего раствора при движении по продуктивному горизонту охватывает не только рудное тело, но и вмещающие горные породы. Процесс протекает непрерывно в замкнутом цикле до тех пор, пока из недр не будет извлечен полезный компонент. По окончании процесса в продуктивном горизонте остается сложный по составу остаточный раствор. Вследствие многократного участия рабочего раствора его минерализация к концу отработки рудного тела достигает 60-80 г/л. Часть сульфат-иона в процессе взаимодействия выводится из раствора вследствие образования нерастворимых веществ, например гипса.

Роль рабочего органа выполняет жидкая фаза, содержащая растворенный реагент. Она же выносит из области взаимодействия продукты выщелачивания. Для рентабельной добычи продукции в обороте необходимо держать большой объем рабочих растворов. Концентрация полезного компонента в продуктивных растворах примерно в 25 раз меньше, чем начальное содержание его в руде. При подземном выщелачивании в недра вводится объем загрязнителей в виде сульфат-иона. Возможны и другие добавки, используемые в качестве окислителя: трехвалентное железо, хлор-ион, поверхностно-активные вещества и другие химикалии.

В недрах набор загрязнителей расширяется вследствие образования новых веществ при взаимодействии реагента с рудами, вмещающими породами и мобилизованным металлом.

Загрязнение поверхностных вод при подземном выщелачивании происходит как непосредственно, так и ветропылевым разносом, подземным стоком, дождевыми и талыми водами. В поверхностные воды попадают пыль, рудный шлам, сульфаты и гидроокислы, растворы ПВ и продукты их взаимодействия с породами.

При подземном выщелачивании загрязнению подвергаются надпродуктивные водоносные горизонты. В редких случаях - при наличии литологофильтрационных окон или гидравлически раскрытых тектонических нарушений - растворы ПВ попадают в подпродуктивный водоносный горизонт в местах и в периоды превышения пьезометрической поверхности продуктивного водоносного горизонта над пьезометрическим уровнем подпродуктивного. Загрязнение надпродуктивных водоносных горизонтов возможно и при нарушениях технологии строительства скважин в контуре выщелачивания.

Каналами связи продуктивного и надпродуктивного водоносных горизонтов могут являться некачественно ликвидированные скважины. При попадании растворов выщелачивания 
в вышележащую толщу загрязнение может распространяться на значительное расстояние или локализуется технологическими мерами.

Продуктивный водоносный горизонт в пределах контура отработки загрязняется весьма существенно, а распространение загрязнений за контур отработки зависит от системы отработки и гидрологических условий локализации оруденения.

Взаимодействие подземных вод с вмещающими их горными породами является аналогом процесса выщелачивания слабой интенсивности. В подземных водах содержатся все компоненты растворов подземного выщелачивания.

Процессы водной миграции веществ делятся на три группы:

- химические: растворение, выщелачивание, сорбция, ионный обмен, образование осадка, окисление, восстановление;

- биохимические: результат жизнедеятельности микроорганизмов с синтезом и разложением вещества;

- физические: подвижность, концентрирование, испарение, рассеяние, смешение, диффузия, гравитационная дифференциация (табл. 2).

С увеличением глубины работ степень минерализации увеличивается, а состав упрощается и приближается к мономинеральному.

Подземная гидросфера представляет собой совокупность и чередование связанных между собой гидрогеологических структур, открытых на выступах фундамента и закрытых в депрессиях. Чем меньше гидрогеологическая структура в плане, тем больше она близка к поверхностным водам. В этом же направлении улучшаются условия фильтрации и промывания пород, что способствует формированию в приповерхностной части литосферы слабоминерализованных гидрокарбонатных подземных вод.

В районе месторождения полезных ископаемых в вертикальном разрезе возникают зоны:

- приповерхностная зона обитания живого вещества;

- промежуточная зона, отделяющая зону локализации от запасов сырья;

- глубинная зона локализации полезных ископаемых.

Таблица 2. Систематизация компонентов растворов подземного выщелачивания

Table 2. Systematization of the components of in situ leaching solutions

\begin{tabular}{|l|l|l|l|}
\hline \multicolumn{1}{|c|}{ Группы } & \multicolumn{1}{|c|}{ Компоненты } & \multicolumn{1}{|c|}{ Процессы } & \multicolumn{1}{|c|}{ Продукты } \\
\hline $\begin{array}{l}\text { Сильные } \\
\text { мигранты }\end{array}$ & $\mathrm{Na}^{+}, \mathrm{Cl}^{-}$ & $\begin{array}{l}\text { Разбавление, обмен с комплексом } \\
\text { поглощенных оснований, } \\
\text { депонирование в пористости }\end{array}$ & Новообразования \\
\hline $\begin{array}{l}\text { Умеренные } \\
\text { мигранты }\end{array}$ & $\begin{array}{l}\mathrm{Ca}^{2+}, \mathrm{Mg}^{2+}, \mathrm{NH}_{4}^{+}, \\
\mathrm{K}^{+}, \mathrm{SO}_{4}^{2-} \text { и др. }\end{array}$ & $\begin{array}{l}\text { Химические реакции, сорбция, } \\
\text { десорбция, биохимические процессы, } \\
\text { автометаморфизм, окисление, } \\
\text { восстановление, депонирование }\end{array}$ & $\begin{array}{l}\text { Нерастворимые } \\
\text { и слаборастворимые вещества, } \\
\text { сульфатоемкие вещества, газы, } \\
\text { биомасса }\end{array}$ \\
\hline $\begin{array}{l}\text { Слабые } \\
\text { мигранты }\end{array}$ & $\begin{array}{l}\mathrm{Fe}^{3+}, \mathrm{Fe}^{2+}, \mathrm{Al}^{3+} \\
\text { др. }\end{array}$ & $\begin{array}{l}\text { Химические реакции, сорбция, } \\
\text { десорбция, биохимические процессы, } \\
\text { автометаморфизм, окисление, } \\
\text { восстановление, депонирование, } \\
\text { гидролиз }\end{array}$ & $\begin{array}{l}\text { Нерастворимые } \\
\text { илаборастворимые вещества, } \\
\text { сульфатоемкие вещества }\end{array}$ \\
\hline
\end{tabular}


Зона локализации представляет собой обводненный стратиграфический или литологический горизонт или комплекс, расположенный между водоупорами. Промежуточная зона состоит из стратиграфических или литологических горизонтов, среди которых могут быть и водоносные. Если промежуточная зона оказывается маломощной или отсутствует, месторождение располагается в зоне обитания.

Зона обитания включает почвы, породы зоны аэрации и грунтовых вод, грунтовые и поверхностные воды, приповерхностные части атмосферы, растительный и животный мир. Конгломераты, брекчии, метаморфические и изверженные породы обводнены - от мощных потоков грунтовых вод в долинах рек до заболоченностей. Широко развиты поверхностные воды - постоянные и временные водотоки, водоемы, болота, в которых в значительных количествах формируются донные осадки. Твердая и жидкая фазы пронизываются газовой фазой: воздушные газы растворены в поверхностных и грунтовых водах, насыщают породы зоны аэрации и почвы; сама атмосфера, особенно в приземной части, содержит компоненты литосферы, гидросферы и биосферы в виде аэрозолей, паров и бактерий.

Технологии разработки месторождений различаются местом извлечения металлов из руд. При традиционных технологиях разработки вся добытая горная масс извлекается на земную поверхность для переработки. Хвосты переработки размещаются в хранилищах, которые становятся зонами инфильтрации жидкой фазы в подстилающие породы и грунтовые воды.

Шахтные воды, извлеченные на поверхность, содержат вредности в мобильном состоянии в виде растворов и взвесей. Они попадают после очистки, а чаще без нее, в гидрографическую сеть. Активированный источник загрязнений влияет на зону обитания (рис. 3).

При отработке месторождений выщелачиванием ни руда, ни подземные воды из недр на поверхность не извлекаются, за исключением части руд при создании компенсационного пространства для разрыхляемых руд. Наоборот, в недра вводятся химически активные и биологически опасные вещества для перевода полезных компонентов в раствор (рис. 4).

Транспортировка добываемых продуктивных и рабочих растворов осуществляется с помощью трубопроводного транспорта в замкнутом пространстве. Главным объектом воздей-

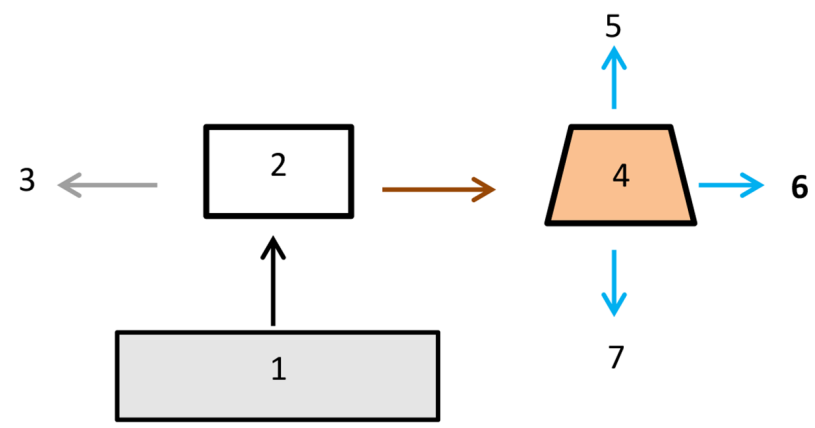

Рис. 3. Движение потоков при разработке традиционными способами: 1 - месторождение; 2 - цех переработки руд; 3 - концентрат; 4 - хранилище хвостов переработки; 5 - вода в атмосферу; 6 - вода в гидросферу; 7 - вода в литосферу

Fig. 3. The movement of flows during development by traditional methods: 1 - field; 2 - ore processing shop; 3 - concentrate; 4 - repository tailings repository; 5 - water to the atmosphere; 6 - water in the hydrosphere; 7 - water to the lithosphere 


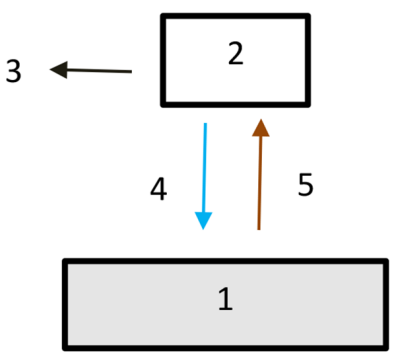

Рис. 4. Движение водных потоков при разработке выщелачиванием: 1 - месторождение; 2 - цех переработки растворов; 3 - концентрат; 4 - раствор реагента; 5 - продукционный раствор

Fig. 4. The movement of water flows during development by leaching: 1 - field; 2 - solution processing workshop; 3 - concentrate; 4 - reagent solution; 5 - production solution

ствия процесса добычи металлов является не зона обитания, а зона локализации полезных ископаемых, где риск загрязнения поверхности, воздуха, вод может быть исключен.

Зона обитания и зона изоляции загрязняются в случае нарушения технологии добычи, переработки, хранения и транспортировки готового продукта и использования реагентов и материалов.

В недрах остаются растворы подземного выщелачивания с частью реагентов, продуктов реакций и хвостами выщелачивания, которые могут выйти за пределы контура отработки и продвинуться по потоку на расстояние, обусловленное параметрами движения подземных вод.

Остаточные растворы могут проникнуть и в смежные водоносные горизонты при наличии с ними естественной или искусственной гидравлической связи, тектонических нарушений или при землетрясениях.

Предприятие подземного выщелачивания является аналогом полигонов подземного захоронения жидких промышленных стоков, отличаясь тем, что рудник выщелачивания строят в локализующей месторождение геологической структуре, в то время как для полигонов подземного захоронения выбирают отвечающие определенным требованиям структуры.

Сравнение способов разработки месторождений показывает, что для водных ресурсов добывающего региона наиболее опасны традиционные технологии с образованием в земной коре выемкой руд полостей, служащих дреной для поверхностных и подземных вод. Их фильтрация сквозь породы повышает минерализацию и делает опасными при выдаче вод на земную поверхность.

Технологии же с выщелачиванием при нормальном режиме работ для водных ресурсов не опасны, поскольку пустот не образуется или они заполняются хвостами подземного выщелачивания, а водные потоки перемещаются в замкнутом, легко контролируемом пространстве, например, по трубопроводам или обсаженным скважинам.

Подтверждением этого является практика уранодобывающего предприятия на базе Быкогорского месторождения. В течение почти 30 лет уран добывали выщелачиванием сернокислыми растворами на расстоянии 7 км от бальнеологического курорта с использованием для лечения минеральных вод. Смешивание питьевых вод и промышленных стоков предотвращалось путем создания технологического барьера с помощью вакуумных насосов.

Экономико-математическая модель для определения ущерба, наносимого выбросом неочищенных производственных стоков в окружающую среду, имеет 


$$
Y_{c m}=\sum_{1}^{n} V_{s} \sum_{1}^{m} K_{t} \bigsqcup_{s}
$$

где $V_{2 m}$ - экономический ущерб, наносимый гидросфере технологическими комплексами; $V_{6}-$ объем природной воды; $K_{T}$ - коэффициент технологического загрязнения природной воды; $L_{6}$ - цена воды; $n$ - количество источников воды; $m$ - количество технологических комплексов.

Рассматриваемые в настоящем исследовании вопросы представляют интерес при модернизации технологий разработки металлических месторождений в регионах с минимизацией негативного влияния на водные ресурсы и согласуются с результатами исследований по рассматриваемому направлению горного дела $[17,18]$.

\section{Заключение}

Влияние горного производства на водные ресурсы состоит в повышении минерализации природных вод после контакта их с обнаженными и подробленными рудами и породами в выработанном пространстве и смешивании загрязненных вод с условно чистыми водами.

Конверсия горного производства на технологии с выщелачиванием ставит задачи мониторинга взаимодействия рудничных и природных водных потоков, которые должны решаться на стадии подготовки месторождения к эксплуатации.

Негативное влияние горного производства на водные ресурсы региона минимизируется использованием технологий разработки с выщелачиванием металлов из руд на месте их локализации.

\section{Список литературы / References}

[1] Дмитрак Ю.В., Голик В.И., Вернигор В.В. Геомеханические предпосылки сохранения устойчивости выработок при разработке водообильных месторождений. Известия Тульского государственного университета. Науки о Земле. 2018. 1. 218-229. [Dmitrak Yu.V., Golik V.I., Vernigor V. V. Geomechanical prerequisites for maintaining the stability of workings in the development of water-rich deposits. Bulletin of the Tula State University. Earth Sciences. 2018.1.218229. (in Russian)].

[2] Каплунов Д.Р., Рыльникова М.В., Радченко Д.Н. Проблема использования возобновляемых источников энергии в ходе разработки месторождений твердых полезных ископаемых. Физико-технические проблемы разработки полезных ископаемых, 2015, 1, 88-96. [Kaplunov D. R., Rylnikova M.V., Radchenko D.N. The problem of using renewable energy in the development of solid mineral deposits. Physical and technical problems of mining, 2015, 1, 88-96. (in Russian)].

[3] Комащенко В.И., Васильев П.В., Масленников С.А. Технологиям подземной разработки месторождений КМА - надежную сырьевую основу. Известия Тульского государственного университета. Науки о Земле, 2016, 2, 101-114. [Komashchenko V.I., Vasiliev P. V., Maslennikov S. A. KMA underground mining technologies are a reliable raw material base. Bulletin of Tula State University. Earth Sciences, 2016, 2, 101-114. (in Russian)].

[4] Геомеханические и аэрогазодинамические последствия подработки территорий горных отводов шахт Восточного Донбасса/ Н. М. Качурин, Г. В. Стась, Т. В. Корчагина, М. В. Змеев. Известия Тульского государственного университета. Сер. Науки о Земле. Вып. 1. 2017. С. 170 
182. [Geomechanical and aerogasdynamic consequences of undermining the territories of allotments of mines in the Eastern Donbass. Kachurin, G. V. Stas, T. V. Korchagina, M. V. Zmeev. Bulletin of the Tula State University. Ser. Earth Sciences. 1. 2017. 170-182. (in Russian)].

[5] Голик В.И., Комащенко В.И. Отходы обогащения железистых кварцитов как сырье для доизвлечения металлов и использования в качестве закладочных смесей. Горный журнал. 2017, 3, 43-47. [Golik V. I., Komashchenko V. I. Ferrous quartzite enrichment waste as a raw material for additional extraction of metals and use as filling mixtures. Mountain Journal. 2017, 3, 43-47. (in Russian)]

[6] Клюев Р. В., Босиков И. И., Майер А. В., Гаврина О. А. Комплексный анализ применения эффективных технологий для повышения устойчивого развития природно-технической системы. Устойчивое развитие горных территорий, 2020, 2, 283-290. [Klyuev R. V., Bosikov I.I., Mayer A. V., Gavrina O. A. Comprehensive analysis of the use of effective technologies to improve the sustainable development of the natural and technical system. Sustainable development of mountainous areas, 2020, 2, 283-290. (in Russian)]

[7] Голик В.И., Лукьянов В.Г., Хашева 3. М. Обоснование возможности и целесообразности использования хвостов обогащения руд для изготовления твердеющих смесей. Известия Томского политехнического университета. Инжиниринг георесурсов. 2015. Т. 326. № 5. С. 6-14. [Golik V.I., Lukyanov V.G., Hasheva Z.M. Substantiation of the possibility and expediency of using ore dressing tailings for the production of hardening mixtures. Bulletin of the Tomsk Polytechnic University. Engineering of georesources. 2015. 326, 5, 6-14. (in Russian)].

[8] Xiao Li-ping. Study on Pollution Laws of Coal Gangue Leaching Solution to Groundwater System. Fuxin: Liaoning Technical University. 2007. 345-356.

[9] Амбросимов А.К. О стоке придонных вод Северного Каспия по палеоканалам в Дербентскую котловину. Водные ресурсы, 2015, 4, 380-387 [Ambrosimov A.K. About the runoff of bottom waters of the North Caspian through paleochannels to the Derbent Basin. Water Resources, 2015, 4, 380-387. (in Russian)].

[10] Игнатчик В. С., Кузнецов П.Н. Оптимизация систем водоснабжения и водоотведения. Вода и экология: проблемы и решения. 2016, 4, 26-35 [Ignatchik V. S., Kuznetsov P.N. Optimization of water supply and sanitation. Water and ecology: problems and solutions. 2016, 4, 26-35, (in Russian)].

[11] Качурин Н. М., Левковская В.В. Теоретическое обоснование закономерностей движения загрязненных шахтных вод в очистных фильтрах. Известия Тульского государственного университета. Науки о Земле, 2016, 3, 81-87. [Kachurin N. M., Levkovskaya V. V. Theoretical substantiation of the patterns of movement of contaminated mine water in sewage filters. Bulletin of Tula State University. Earth Sciences, 2016, 3, 81-87. (in Russian)].

[12] Крупская Л.Т., Голубев Д.А., Волобуева Н.Г. Оценка экологической ситуации территории в зоне влияния хвостохранилища с токсичными отходами. Современные тендениии развития науки и технологий, 2016, 1-2, 97-100. [Krupskaya L.T., Golubev D.A., Volobueva N. G. Assessment of the ecological situation of the territory in the zone of influence of the tailing dump with toxic waste. Modern trends in the development of science and technology, 2016, 1-2, 97-100. (in Russian)].

[13] Лискова М. Ю. Негативное воздействие, оказываемое на окружающую среду предприятиями по добыче и обогащению калийно-магниевых солей. Вестник Пермского националь- 
ного исследовательского политехнического университета. Геология. Нефтегазовое и горное дело. 2017. 16, 1, 82-88. [Liskova M. Yu. The negative impact on the environment of the enterprises for the extraction and enrichment of potassium and magnesium salts. Bulletin of the Perm National Research Polytechnic University. Geology. Oil and gas and mining. 2017. 16, 1, 82-88. (in Russian)].

[14] Broder J. Merkel, Britta Planner-Freidrich. Groundwater Geochemistry-A pratical guide to modeling of natural and contaminated aquatic systems. Springer, Berlin, 2005, 230-238.

[15] Голик В.И., Урумова Ф. М., Масленников С. А., Небылова Я. Г. К проблеме химизации окружающей среды при добыче металлических руд в горных регионах. Безопасность труда в промышиенности. 2020. 8, 53-59. [Golik V.I., Urumova F. M., Maslennikov S. A., Nebylova Ya.G. On the problem of chemicalization of the environment during the extraction of metal ores in mountainous regions. Labor safety in industry. 2020. 8, 53-59. (in Russian)].

[16] Голик В.И., Разоренов Ю.И., Каргинов К.Г. Основа устойчивого развития РСОАлания - горнодобывающая отрасль. Устойчивое развитие горных территорий. 2017, 9.2 (32), 163-171. [Golik V.I., Razorenov Yu.I., Karginov K. G. The basis of sustainable development of North Ossetia-Alania is the mining industry. Sustainable development of mountain areas. 2017, 9.2 (32), 163-171. (in Russian)]

[17] Дмитрак Ю.В., Шишканов К.А. Разработка вероятностной кинематической модели мелющих тел в помольной камере вибрационной мельницы. Горный информационноаналитический бюллетень (научно-технический журнал). 2010. 12, 302-308. [Dmitrak Yu.V., Shishkanov K. A. Development of a probabilistic kinematic model of grinding bodies in the grinding chamber of a vibration mill. Mining information and analytical bulletin (scientific and technical journal). 2010. 12, 302-308. (in Russian)]

[18] Yu S., Yang J., Liu G., Yao R., Wang X. Improvement for the multi-scale periodic characteristics revealing of precipitation signals and its impact assessment on soil hydrological process by combining HHT and CWT approaches. Natural Hazards and Earth System Sciences, 2015, 15, 393-407.

[19] Комащенко В. И., Голик В. И., Белин В. А., Гапоненко А. Л. Повышение эффективности взрывной отбойки на основе новых способов инициирования скважинных зарядов на карьерах. Горный информационно-аналитический бюллетень (научно-технический журнал). 2014, 9, 293-304. [Komashchenko V.I., Golik V.I., Belin V. A., Gaponenko A. L. Improving the efficiency of explosive blasting based on new methods for initiating borehole charges in quarries. Mountain Information and Analytical Bulletin (scientific and technical journal). 2014, 9, 293-304. (in Russian)].

[20] Дубровская О.Г., Евстигнеев В.В., Кулагин В.А. Кондиционирование сточных вод энергетических систем и комплексов. Журнал Сибирского федерального университета, Техника и технологии, 2011, 6(4), 665-675. [Dubrovskaya O.G., Evstigneev V.V., Kulagin V.A. Waste water conditioning energy systems and complexes. Journal of the Siberian Federal University, Technika and Technologies, 2011, 6 (4), 665-675. (in Russian)].

[21] Габараев О.3., Дмитрак Ю. В., Дребенштедт К., Савелков В. И. Закономерности взаимодействия разрушенных геоматериалов и рудовмещающего массива при отработке подработанных вкрапленных руд. Устойчивое развитие горных территорий. 2017. 9, 4(34), 406-413. [Gabaraev O.Z., Dmitrak Yu.V., Drebenstedt K., Savelkov V. I. Regularities of interaction of destroyed geomaterials and ore-bearing massif during mining of underworked disseminated ores. Sustainable development of mountainous areas. 2017. 9, 4(34), 406-413. (in Russian)]. 